\title{
Livelihood Challenges and Strategies: The Valmikis of Eastern Ghats*
}

\author{
K.E. Rajpramukh and P.D.S Palkumar \\ Department of Anthropology, Andhra University, Visakhapatnam 530003, \\ Andhra Pradesh, India \\ E-mail: rajpramukh@yahoo.com
}

KEYWORDS Valmikis. Tribe. Strategies. Economic and Political Roles

\begin{abstract}
Eastern Ghats are inhabited by numerous tribal groups. Prominent among them in the north coastal districts of Andhra Pradesh are: Bagathas, Konda Doras, Jatapus, Savaras, Gadabas, Porjas, Khonds and Valmikis. Tribals usually have to constantly cope up with different trying situations exacerbated by scarcity of food, poverty, ill-health, lack of information and illiteracy etc., and they face these challenges working out their own strategies which are naïve in some instances and innovative in others. Valmiki is an interesting case in this context. Valmikis are placed at the lowest in the tribal hierarchy. They have a social status equivalent to that of the Dalits of the plains areas. Of late, they could progress astonishingly well in all areas of social and economic life much better than all the other neighboring tribes. Petty trade and Money lending business, which established a sound economic base for them, were to a large extent responsible for their phenomenal progress. With better economic status, they could improve their educational status and eventually started donning political roles. At present, with their emergence as leaders in different areas, they are even competing with the Bagathas, the dominant priestly tribe, in economic and political domains. This paper illustrates the success story of Valmikis, vis-à-vis other tribals, despite many structural disadvantages, over three generations bringing out the role of tribal values and attitudes in exploiting the resources available in their environment. The strategies adopted in this context are three fold viz., adhering to traditional roles and performances, building strong economic base through education and occupying political roles.
\end{abstract}

\section{INTRODUCTION}

Visakhapatnam agency is home for about 20 tribal groups who eke out their livelihood from a range of occupations that include hunting, gathering minor forest produce, horticulture, slash-and-burn agriculture, and dry- wet cultivation, etc. Multi-tribal villages are common all over the agency and depending upon the tribal composition of a village, all the groups are arranged in a social ranking based on high and low positions that conform to the social order in other villages ${ }^{1}$. The Bagatha occupy the highest position followed by the Kotiya and the Valmiki is assigned the lowest position. The expressions of social hierarchy can be observed at different socio-political and religious contexts that include spatial distance of dwellings, endogamous marriages, commensal relations, socio-ritual distance, traditional occupational practices and traditional political positions of every village (Reddy, N.S., 1973). The residence pattern of higher tribes occupying the land with higher elevation leaving low lying land to the lower groups to construct their houses conforms with the social order. The

*(Paper presented at the International conference on 'Livelihood strategies among forest-related tribals of South India' held at Dvanyaloka centre for Indian Studies, Mysore, from17 - 19 of October, 2003) same idea can be observed in the burial ground where the higher tribes like Bagatha and the Kotiya bury their dead at a demarcated higher elevation with elaborate memorial structures which show that a person from a lower group is lowly even in the burial ground. The non-tribal groups are also fitted into this order of residence and burial.

The religious aspects tend to rationalize the ideology behind this tribal hierarchy. A clear categorization of animate and inanimate things into clean and unclean is observed. Food is differentiated into clean and unclean and the groups that eat unclean food are found to be occupying lower categories. The Bagatha and Kotiya are the tribes that eat only clean food. The groups that eat beef and pork are Konda Dora, Konda Kammara, Poraja and Valmiki. These groups occupy lower positions in the social order. The Valmiki, who eat dead carrion are treated as the lowest in the order. With regard to the acceptance of the boiled food, the tribes can be graded into those from whom all the tribes accept and from whom no group will accept and all the other tribes can be seen on this continuum.

Traditional occupations are graded, as clean and unclean, and unclean occupations are invariably associated with the groups that are assigned lower positions. While agriculture is 
the common activity, land owning is considered to bring prestige to the owner. The Bagatha and Kotiya in general are the landowners of the agency. Carpentry, black smithy and pottery are not unclean. Pig rearing is considered to be low and therefore, Poraja are also treated as low. Cattle business, removing carcasses, treating the hides are considered to be the lowest occupation and therefore, the Valmiki that practice these menial occupations are the lowest in the social scale.

The stigma is attached to the lower groups even after they abstain from eating unclean foods and gave up occupations graded as polluting. The stigma is hereditary and no rituals can make a person or a group shed away their stigma. The avoidance of lower groups at different contexts reinforces the superiority of the higher groups.

The lower groups such as the Valmiki are not allowed to eat with other tribes when they are at a common feast. Each tribe eats in a separate row. This rule is observed in hunting expeditions and when they go out on camps. However, proximal tribes such as Bagatha, Kotiya can cook together. This socio-ritual distance is maintained in the inter-tribal marriages also. Though endogamy is highly stressed, the village council grants union between proximal tribes with imposition of penalty. However, union between persons belonging to higher tribe with that of inferior tribe is highly opposed and may lead to excommunication of those involved in such marital relations.

The allocation of roles in the festivals indicates that menial jobs and those roles that involve exposure to impurity and danger are reserved for the Valmiki. The village priest is the position occupied by the Bagatha. The Valmiki, besides being the butchers of the sacrificial animals, act as a medium for ancestral spirits and also act as musicians at several socio-ritual occasions. The neighboring tribes believe that the inherent pollution of the lower groups repels the spirits attacking the babies and it is observed in christening the children of higher tribes with Valmiki names. The distinction between pure and impure forms the basis for the tribal interactions.

The control over land that is a basic resource makes the Bagatha a dominant group (Reddy, Muniratnam, 1971) and other tribes depend on them. A system of interdependence among different tribal groups developed in which the landless groups obtain access to the means of subsistence through their dependent relationships with the dominant groups. The exchange of services by the artisan groups and other groups that provide various services to the landowner involve higher prestige to the landowning groups. Agricultural tenants express their respect to those groups and the labourers show obedience towards their masters. This traditional arrangement of inter-dependence based on dependent relationships is further reinforced by religious considerations.

The economic dominance is reflected in the traditional political offices wherein the Bagatha and Kotiya are the village heads, and muttadars all over the Visakhapatnam agency. Other positions of servitude like the village challanu (Assistant) and Barika (Village servant) are occupied by the Porja and the Valmiki, respectively. On the whole, the traditional social hierarchy assigned the Valmiki socially lowest, religiously impure, economically poor and politically sub-ordinate position, which did not allow any possibility to the Valmiki to alter their lowly position.

However, colonial period triggered off many changes in India when the tribal areas were also included in the direct administration by local Zamindars. Communications with the plain areas developed and the petty traders of the plains increased their activities buying more and more forest produce. Groups that are in disadvantaged position in the traditional set-up looked forward for a redressal and made frantic and steady efforts to raise their status in their local social order. The effect of colonial rule is two-fold: The first one being the introduction of new economic forms of exchange like monetary method which displaced the traditional Barter system prevailing among the tribal groups. Secondly, the introduction of education as collateral to missionary activity, was ably utilized by the Valmiki. The conscious attempts by the Valmiki to elevate their position followed many routes to success:

\section{MIDDLEMEN-PETTY TRADE}

The Valmiki, being the landless poor among the tribes used to sell their collection of minor foresh produce in different shandies to the nontribal petty traders. It was at the end of 19th century that the Valmiki acted as middlemen between the cultivating tribes and the traders from plains areas. Other tribes did not take up 
these activities because they considered trade as below their status and land only is important to them. Deprivation and poverty made the landless Valmiki more mobile than the rest of the tribes in the agency. Being in close and active contact with the non-tribal petty traders, the Valmiki middlemen learned the tricks of trading and they could make easy profits in direct barter with the ignorant tribals.

The monetary method of exchange gave them enough leverage by acting as middle-men and brokers between plain-traders, buying forest produce and mobilising the forest produce and offering it for sale. The shrewdness and entrepreneurship of the Valmiki was evident in the commodification of minor forest produce and served as the seed capital. In this process, he established himself as a respectable petty-trader with the plain people and as a money lender to the forward tribals. Soon they started their own business on a small scale selling salt and dry fish in the villages while buying forest and agricultural produce from the villagers. Both males and females of the Valmiki engaged in petty trade. Some Valmikis started buying cattle in the shandies in the plains and sold them to the tribal agriculturist for profits. This cattle business was so profitable for them that they moved from shandy to shandy enhancing their gains.

\section{Opium Licenses}

The Valmiki also took opium licenses from the then Government to sell opium, to the tribals for profit. This, they learned from the Sundis, a liquor trading caste from the plains who prospered through liquor brewing in the hills (Proceedings of the Board of Revenue, letter of H.G. Turner, esq. Collector of Vizagapatam, Govt. of Madras, Revenue Department, Nos. 235, 235A, 1888).

\section{Money Lending and Land Mortgage}

In the process, a comfortable margin of profit was made which was gradually increased by initiation of lending money to the landed groups among the tribals and gradually gaining control over land either through share-cropping in the first stage or later taking over the lands in lieu of the money lent. The indebtedness among the tribals and the increasing wealth among the
Valmiki changed the material distribution in the tribal villages. The Valmikis started taking lands on mortgage, share cropping and finally, buying lands. Thus, by and large, considerable extent of land had to pass from the Bagatha and the Kotiya to the Valmiki. This gradually formed into a respectable economic base over a period covering three generations ${ }^{2}$.

\section{Change of Religion}

In their attempts to shed away the stigma of being a low tribe, many Valmiki changed their religion. Attracted by the welfare activities of the Protestant Christian missionaries and the Christian ethic of equality, many Valmikis converted to Christianity and this process was initiated since the beginning of $20^{\text {th }}$ century. This also brought medical, educational and other material benefits from the missionaries. The Valmiki tried to reassess their position with the new religion. The change gave them, a new dimension in their thinking that they were the followers of the religion of the rulers, i.e. British. New religion brought many changes in their way of life, which they blended with their earlier beliefs.

\section{Change of Identity}

Against the traditional nomenclature of being called as Doms and Konda mala, a new identify 'Valmiki' was formulated in order to avoid the pejorative and derogatory connotative of the earlier ones and to generate a respectable selfimage as the primary condition of new form of life. This change, even though it looks minor, helped to create a new identity as Valmikis in correlation with other changes in his life. The change of nomenclature to Valmiki is after the Sage Valmiki, who wrote the Ramayana was timely appropriated by this group in order to generate respectability among other groups. It may be pertinent here to note that many communities assumed new names as reported in the 1921 census.

An interesting feature among all these evolving changes is that the Valmiki did not avoid their traditional role in the tribal society but consolidated themselves by continuing their ritual role of being musicians and butchers of sacrificial animals and not challenging or antagonizing the established practices. This kind 
of strategy helped them to bring about a smooth change in their life pattern without inviting outright conflict or hostility of the other tribes. In other words, while negotiating a gradual change in their life by using newly found connections and acquisition of wealth and without losing their traditional position, they were able to balance their external activity with their internal position in such away that they became indispensable for various activities. Earlier when the change in their economic position was too overt or challenging to the forward tribes, it resulted in violence and retorts as the following reports attest:

\section{Reaction of the Land Owning Tribes}

While the economic advancement of the Valmiki is more or less uniform all over the agency, this tilt in the balance was not received well by the Bagatha and Kotiya, who were the Village headmen. Incidents of violence unleashed on the Valmiki by the land owning Bagathas and Kotiyas ranged from organized looting to murders. Several such incidences were reported from all over the agency as evident from the records of the Government of Madras since 1880 .

Report of David F Carmichael to the then Govt. of Madras in April 1881 states that "the recently threatened disturbances in Jeypore arising out of the killing of certain Dombs or Pariahs by the villagers under the leadership of headmen or Naidus... The Dombs... are generally weavers and petty merchants.. they do not commonly hold land. Their increased ownership of land became an eyesore to the dominant tribes" (p. 22.). In an another report during 1881-82 Carmichael reports that "In Kotpad,... There was still more irritation against the Dombs.... who were extorting paddy from the ryots at the country fairs".

Intolerance on the part of dominant tribes towards the acquired property of Valmiki is evident from the increased attacks on them. Weekly reports of the Acting Superintendent of Police, Jeypore during 1880-1910 testify these attacks. There were reports that Dombs/Pariahs/ Hill Malas (all synonyms to Valmiki) being killed by the Naidus without any evidence of crime. Generally they attribute instances of stealing and cattle lifting to the Valmikis. In the attacks, the participation of all other tribes is a point worthy to be taken note of.
H.G. Turner, the then Agent to the Governor of Vizagapatam in his report on 22-77-1886 from Chintapalle writes that "there is ill-feeling between muttadars and their tenants or between the cultivating classes generally and trading classes, who are the Pariahs. So we have an evidence of a disturbance that took place in one of the local markets in January in these hills, when some of higher classes said that in six months time they would cut the pariahs into pieces like 'calabashes' (p. 15).

W.D. Horne, the then Agent to the Governor, Vizagapatam reports on 15-7-1899 that 'the Dombs who are the Panchamas of that part of the Agency, and whose nominal occupations are weaving and petty-trade really live .... by blackmail and extorting from the other classes of the population. Accordingly the Naiks of 16 villages headed an organized attack on the houses of the Dombs, which in a most deliberate manner they razed and destroyed in some 15 villages' (p. 2).

The Government Order No. 1173, Judicial of 1900 describes such incidents in Gudem and Madgode. Another GO No. 1371, Judicial of 27-1901 is a report by S.F. Bryant, the then Agent who writes that "the Jarrela case is interesting for several reasons. In the first place it shows that the Bagatha, who regard themselves as the lords of the hills are beginning to regard with envious eyes the growing prosperity of the Hill Malas. The dacoit was infact, nothing but a loot of a rich pariah village by some 50 or 60 Bagathas".

All these instances clearly attest to the fact that there were attempts by the higher tribes to check the prosperity of the Valmiki. The Valmiki could maintain this momentum and their ability to extend and convert the situations conductive to them even in the post-Independent India. The survival strategy of the Valmiki paid off in injecting a new form of economic progress and life. By the time the landed groups realised, the Valmiki were able to place themselves in an entrenched position either due to their connection with beauracracy or litigation or newly acquired economic clout. In other words, he became a crucial negotiator between the plains people and tribals.

The data collected in selected four villages of the Visakhapatnam Agency clearly show that the Valmiki have some hold over land which is a source of tangible wealth in tribal society and 
also treated as a matter of prestige and marker of growth (Table1) The Valmiki have taken advantage of the enactment of anti-land alienation laws which restricted transfer of land from tribals to non-tribals, but permitted transfer of land from tribals to tribals, thus eliminating the non-tribal competition in the tribal area. This has led to the emergence of Valmiki as an 'insider-diku'.

The land tenure system of the Agency do not match with the Governmental system, where in the tribals do not have individual pattas to their lands and still in many cases maintain their common ownership over generations. Due to this reason and also that the procedures of land registration are cumbersome, many Bagatha and Kotiyas could not avail Government loans and subsidies immediately. However, the Valmiki were meticulous enough to follow the land registration procedures through which, they could easily get loans granted.

\section{Literacy}

A crucial factor in the rise of the Valmiki is the increase in literacy which helped them negotiate and form connections with not only traders but also Government agencies and court litigations that strengthened their position among tribal groups and made them indispensable. The evidence shows that literacy levels are higher in Valmiki compared to others thus giving them an initial and definitive advantage over others. (Table 2). Their contact and exposure with the non-tribals facilitated them to gain some educational advantage and they could avail various Governmental programmes and schemes with such awareness. They, in turn, became advisors and role models for other tribal groups in making use of Government assistance. Valmikis know from experience their abilities to improve and education is looked upon as a means of advancement for them. They realized that if one got educated and became a teacher, he/she would draw respect from his/her own tribesmen as well as from other tribes. Government jobs like clerks also gave them access to information about different Government programmes, which in turn, enhanced their economic position. With the help of the economic progress, the Valmiki eyes turned to capture power.

When the traditional village political systems gave way to the modern democratic electoral system in 1962, the Valmiki took advantage of it. While in many villages, the village Naidus occupied the elected positions, the Valmiki could get share of power by getting elected to other offices ${ }^{5}$. Slowly many Valmikis became successful, eliminating many traditional leaders from village presidents to members of legislative assembly. The Valmiki could consolidate from strength to strength and became an alternative to the Bagatha. In that process, they could get the support of other lower tribes.

The ultimate benchmark of success is their inevitable presence in political offices which has become quite common. It is also due to the reason that their contact with the non-tribals places them in an advantageous position over the rest of the

Table 1: Tribe-wise distribution of families according to land-holdings in four villages of Visakhapatnam agency

\begin{tabular}{|c|c|c|c|c|c|c|c|c|c|c|c|c|c|c|c|}
\hline \multicolumn{3}{|l|}{ Selected Villages: } & \multicolumn{13}{|c|}{$\begin{array}{l}\text { Guntaseema of Dumriguda mandal } \\
\text { Jarrela of Chintapalli mandal } \\
\text { Panasaputt of Munchingput mandal } \\
\text { Peddaputt of G. Madugula mandal }\end{array}$} \\
\hline \multirow{3}{*}{$\begin{array}{l}\text { Name of } \\
\text { the Tribe }\end{array}$} & \multicolumn{15}{|c|}{ Name of the village } \\
\hline & \multicolumn{4}{|c|}{$\begin{array}{c}\text { Guntaseema } \\
\text { Size of the land in acres }\end{array}$} & \multicolumn{4}{|c|}{$\begin{array}{c}\text { Jarrela } \\
\text { Size of the land in acres }\end{array}$} & \multicolumn{4}{|c|}{$\begin{array}{c}\text { Panasaput } \\
\text { Size of the land in acres }\end{array}$} & \multicolumn{3}{|c|}{$\begin{array}{c}\text { Peddaput } \\
\text { Size of the land in acres }\end{array}$} \\
\hline & $\begin{array}{c}\text { Land } \\
\text { less }\end{array}$ & $0-5$ & $6-10$ & $\begin{array}{l}11 \& \\
\text { above }\end{array}$ & $\begin{array}{l}\text { Land } \\
\text { less }\end{array}$ & $0-5$ & $6-10$ & $\begin{array}{l}11 \& \\
\text { above }\end{array}$ & $\begin{array}{l}\text { Land } \\
\text { less }\end{array}$ & $0-5$ & $6-10$ & $\begin{array}{l}11 \& \\
\text { above }\end{array}$ & $\begin{array}{l}\text { Land } \\
\text { less }\end{array}$ & $0-56-10$ & $\begin{array}{l}11 \& \\
\text { above }\end{array}$ \\
\hline Bagatha & 4 & 13 & 6 & 4 & 6 & 28 & 11 & 14 & 5 & 12 & 8 & 2 & 2 & 9 & 3 \\
\hline Kotiya & 11 & 36 & 17 & 6 & 14 & 16 & 3 & 1 & 2 & 3 & 1 & - & 4 & 2 & - \\
\hline Konda Dora & 13 & 8 & 1 & - & 12 & 9 & 4 & - & 7 & 11 & 6 & 1 & 8 & 4 & - \\
\hline Konda Kammara & 4 & 1 & 1 & - & 6 & 3 & 1 & - & 3 & 4 & 1 & - & 2 & 3 & - \\
\hline Poroja & 8 & 4 & - & - & 9 & 2 & 2 & - & 11 & 8 & 5 & - & 9 & 7 & - \\
\hline Valmiki & 18 & 21 & 3 & 1 & 19 & 14 & 8 & 1 & 13 & 9 & 1 & - & 21 & 10 & - \\
\hline Others & 7 & 5 & 2 & - & 13 & 6 & 3 & 1 & 16 & 11 & 6 & - & 14 & 8 & 2 \\
\hline
\end{tabular}


tribals. Even in cases where a Valmiki occupied a subordinate position, he wields more influence than the nominal head because of his understanding in dealing with Government agencies and other related matters.

The Bagatha tried to resist the Valmiki through Sanskritization model. They attempted to fix their status in relation to the caste system, claiming the status of Kshatriya ${ }^{6}$. They were successful in such an attempt to a large extent. They tried to project this new status in their own tribe-tribe context. By this, they could gain the support of Hindu religious cults that were operating in the tribal areas. The Bagatha could continue to consolidate their political power by these means. However, in spite of this opposition the resilient Valmiki, still maintain their political clout and economic position.

It is a very interesting social phenomenon and also a perception from below about the progress of the depraved Valmiki from a menial stage to that of positions of power, which in the Indian context is of great significance as there is an inevitable relationship between social status and political power. This progress can be structured and presented as a new paradigm. The following characteristics can be pointed out as the main features of the paradigm of social change in tribal communities:

- Adequate economic and financial surplus as the basis for other changes as in the lives of the Valmiki.

Table 2: Statement showing percentage of literacy tribe-wise and sex-wise among Scheduled Tribes of Andhra Pradesh in 1961,1971 and 1981

\begin{tabular}{|c|c|c|c|c|c|c|c|c|c|c|}
\hline \multirow{2}{*}{$\begin{array}{l}\text { S. } \\
\text { No. }\end{array}$} & \multirow[t]{2}{*}{ Tribe } & \multicolumn{3}{|c|}{1961} & \multicolumn{3}{|c|}{1971} & \multicolumn{3}{|c|}{1981} \\
\hline & & Male & Female & Total & Male & Female & Total & Male & Female & Total \\
\hline 1. & Andh & 8.39 & 0.14 & 4.50 & 17.81 & 1.68 & 10.07 & 13.77 & 3.10 & 8.54 \\
\hline 2. & Bagatha & 10.70 & 1.03 & 5.98 & 11.72 & 1.35 & 6.62 & 14.70 & 2.16 & 8.52 \\
\hline 3. & Chenchu & 8.55 & 3.20 & 5.95 & 8.02 & 3.98 & 6.69 & 13.34 & 5.92 & 9.71 \\
\hline 4. & Bhil & 51.11 & 2.63 & 28.91 & 13.55 & 2.45 & 7.86 & 28.67 & 8.33 & 19.92 \\
\hline 5. & Gadaba & 4.00 & 1.04 & 2.52 & 5.00 & 1.20 & 3.43 & 10.60 & 3.04 & 10.59 \\
\hline 6. & Gond & 5.02 & 0.26 & 2.65 & 5.97 & 2.57 & 4.35 & 10.27 & 1.25 & 5.75 \\
\hline 7. & Godugu & 7.46 & 1.12 & 4.27 & - & - & - & 21.46 & 13.29 & 17.41 \\
\hline 8. & Hill Reddy & 4.32 & 0.92 & 2.62 & 6.78 & 1.53 & 4.23 & 20.67 & 7.76 & 14.57 \\
\hline 9. & Jatapu & 6.61 & 1.38 & 4.00 & 7.49 & 1.41 & 4.48 & 14.40 & 4.85 & 9.63 \\
\hline 10. & Kammara & 4.84 & 0.94 & 2.90 & 12.47 & 2.92 & 7.76 & 12.15 & 4.31 & 8.26 \\
\hline 11. & Katunayakan & 3.45 & - & 1.35 & 24.81 & 7.50 & 15.22 & 35.12 & 17.01 & 26.32 \\
\hline 12. & kolam & 1.78 & 0.09 & 0.94 & 2.57 & 0.19 & 1.36 & 5.20 & 1.29 & 3.26 \\
\hline 13. & Konda Dora & 5.36 & 1.07 & 3.22 & 5.09 & 0.97 & 3.29 & 9.07 & 2.45 & 5.79 \\
\hline 14. & Konda Kapu & 8.07 & 1.98 & 5.07 & 8.12 & 2.70 & 5.50 & 22.51 & 14.33 & 18.49 \\
\hline 15. & Kondareddi & 3.09 & 0.64 & 1.85 & 6.68 & 1.90 & 4.25 & 11.13 & 4.44 & 7.77 \\
\hline 16. & Khond & 1.79 & 0.15 & 1.01 & 1.52 & 0.25 & 0.92 & 2.09 & 0.36 & 1.26 \\
\hline 17. & Kotia;Benthoria & 5.80 & 0.74 & 3.32 & 9.80 & 1.10 & 5.45 & 15.15 & 4.40 & 9.71 \\
\hline 18. & Koya & 4.88 & 1.04 & 2.97 & 6.45 & 1.39 & 3.93 & 11.86 & 3.88 & 7.89 \\
\hline 19. & Kulia & 5.00 & 2.22 & 3.53 & 7.83 & 2.03 & 4.58 & 16.67 & 6.09 & 11.62 \\
\hline 20. & Mali & 11.13 & 3.64 & 7.41 & 13.03 & 1.67 & 7.53 & 16.49 & 2.79 & 9.73 \\
\hline 21. & Mannedora & 8.91 & 5.66 & 7.17 & 9.34 & 1.96 & 5.61 & 9.89 & 3.49 & 6.72 \\
\hline 22. & Mukadora & 5.08 & 0.68 & 2.95 & 3.60 & 0.26 & 1.95 & 6.08 & 1.54 & 3.84 \\
\hline 23. & Nayak & 10.52 & 1.59 & 8.79 & 10.39 & 0.74 & 5.44 & 8.67 & 2.20 & 5.48 \\
\hline 24. & Pardhan & 9.63 & 0.52 & 4.78 & 15.18 & 2.58 & 8.72 & 25.76 & 5.16 & 15.38 \\
\hline 25. & Porja & 3.31 & 0.26 & 1.82 & 4.53 & 0.18 & 2.39 & 5.06 & 0.70 & 2.88 \\
\hline 26. & Reddidora & 4.15 & 0.26 & 2.20 & 3.49 & 0.23 & 1.86 & 4.21 & 0.81 & 2.54 \\
\hline 27. & Rona Rena & - & - & - & 14.29 & - & 8.33 & 5.97 & 2.04 & 4.31 \\
\hline 28. & Savara & 12.67 & 0.40 & 6.61 & 17.74 & 6.59 & 12.99 & 31.40 & 2.90 & 17.94 \\
\hline 29. & Sugali & 7.68 & 1.61 & 4.72 & 10.11 & 2.63 & 6.48 & 9.94 & 1.88 & 6.02 \\
\hline 30. & Thoti & 22.10 & 1.15 & 12.09 & 17.74 & 6.59 & 12.99 & 31.40 & 4.88 & 17.94 \\
\hline 31. & Valmiki & 18.57 & 2.97 & 10.71 & 20.09 & 5.02 & 12.87 & 28.38 & 10.03 & 19.37 \\
\hline 32. & Yanadi & 7.53 & 2.16 & 4.84 & 8.46 & 3.07 & 5.85 & 10.73 & 4.54 & 7.74 \\
\hline \multirow[t]{3}{*}{33.} & Yerukula & 12.23 & 3.71 & 8.03 & 15.28 & 5.02 & 10.23 & 20.83 & 8.04 & 14.55 \\
\hline & Total & 7.26 & 1.48 & 4.41 & 8.47 & 2.13 & 5.34 & 12.02 & 3.46 & 7.82 \\
\hline & Gen.Pop.of A.P & 30.18 & 12.03 & 21.19 & 33.19 & 15.75 & 21.57 & 39.30 & 20.40 & 29.90 \\
\hline
\end{tabular}

Source: Census Reports of 1961, 1971 and 1981 
- Literacy and entry into various Government Jobs giving them access to information as well as influence in beaurocracy.

- Gradual shift in cultural position from being treated as a menial labourer and the member of the lowest strata to that of a successful negotiator.

- Pragmatic equality in all matters dealing with several economic and political issues, though nominally still being regarded as social and ritual inferior.

- Acquiring a label of respectability by the change of nomenclature from Domb and Konda Mala to Valmiki.

- Access to new Government programmes and knowledge of how to utilise them.

- Capturing of Political offices either at the local level or at the level of State legislature and becoming an indispensable negotiator between the higher echelons of Government and his own tribal groups.

- The present status of the Valmiki is a respected one and a model for the rest of the groups in terms of abilities.

Social hierarchy and differentiation is common among the tribes throughout the Eastern Ghats as well as other regions. All the above factors can be fitted into a new paradigm depicting progress in tribal areas. It helps to bring about changes based on equality without generating conflict or violence.

\section{CASE STUDIES}

Setti Tammanna (65): Thammanna is a native of Guntaseema village in Dumriguda mandal, near Araku. He is a valmiki and his family has been engaged in business as middle-men for a longtime. He recalls that his grand-father used to go around nearby shandies and even to the shandies of Madugula and Srunga-varapukota for buying cattle and selling them to local tribes. His grandfather also obtained license for selling Nallamandu (opium) in 1917 and he used to buy it in the Government store at Srunga-varapukota and sell it in retail to the tribals. His father, Setti Ammanna continued this profession and when Government stopped use of opium, he shifted to petty trade in the local shandies. They do not own any land but his grandfather used to engage in share-cropping in other villages when some Bagathas failed to pay back their loans. Subsequently, his father, due to his success in his business and money lending bought several kuntams of different types of land in the surrounding villages (in terms of acres, it can be calculated as 25 acres approximately). Tammanna, who studied up to upper-primary level at a missionary school at Narsipatnam, has become the first elected vice-president of his village when the traditional peddala panchayat was replaced by democratic village panchayat system, which was introduced in 1962. The village Naidu (Headman), who belongs to Bagatha tribe in the traditional peddala panchayat became the village President and the villagers elected Tammanna as Vice-president because of his education and the ability to deal with the non-tribal officers. Tammanna, presently cultivates 12 acres of land and is an adviser to many land disputes in this region. L.B. Dukku, who for a long period was an M.L.A of Araku (S. Kota constituency) is a close relative of Tammanna and also Setti Lakshmanudu, who served as Chairman, Girijan Cooperative Corporation of Andhra Pradesh. Tammanna says that many Valmiki are successful in securing political leadership in many villages of the Agency and in almost all the villages the Valmiki has a considerable political clout. He explains that conscious attempts by the Valmiki to become successful in economic and political fields made the Bagatha and other tribes to accuse the Valmiki as tricksters, cheats and deceitful. Tammanna's father converted to Christianity and his father used to run a church in a thatched hall in Guntaseema, which is now developed into a pucca building. His eldest son, Mohan Rao (39) is a high school teacher at Hukumpeta and his younger son is a clerk in the I.T.D.A. office, Paderu. Tammanna is one among many Valmikis who are successful in petty trade in Agency.

Arji Ananda Rao (58): He is a resident of Nakkalaputtu, near Paderu. He owns a shop at Paderu and he sells a variety of items there. He started as middleman at the Paderu shandy following his father, Arji Gundu and soon took up trading tamarind, turmeric and pippal root to the shaukars (traders) from the plains. He was so enterprising that he started a small hotel, twenty-two years back at the shandy, Paderu. He has taken a loan from I.T.D.A. and started a bicycle rental shop and also purchased a mike set. He says that he was the first to own a mike set among the tribes and made good money on it. He has nearly 17 acres of land and is engaged 
in a variety of occupations including coffee plantation, money lending owning rental autos and jeeps. Others say that he has made handsome money by involving in the mining semi-precious stones available in these hills and selling them to traders, which is banned by the state Government. He says that the urge to develop is more among the Valmiki and therefore they make use of all possible means to come up in life. Education and readiness to learn are the driving forces in the Valmikis success, he maintains.

\section{NOTES}

1. The presence of multi-tribal villages in the Eastren Ghats is characterized by social differentiation. In Adilabad (Furer- Haimendorf 1945; 1948), East Godavari (Murty, 1972), Srikakulam (Pareek, 1977) Madhya Pradesh (Hivale 1946) Bastar (Thasu, 1959; 1965; Fucks, 1960), Nilgiris (Mandelbaum, 1956), the relative ranking of the tribes was reported.

2. A trans-generational survey of land holding among the Valmiki is conducted by asking the respondents : "What was the total land owned or cultivated by your grand father and father ?" Their responses clearly show that very few of their grand parents owned or cultivated land. It was found that the pattern is similar in all the four villages namely, Guntaseema, Jarrela, Panasaputt and Peddaput.

3. The tribe which is now being referred to as Valmiki was called as Domb and Konda mala by the other tribal groups. The colonial reports of the 19th and early 20th century recorded them as Hill malas, Malas, Dombs, Hill Pariah and Panchamas of the Agency which clearly refer to the untouchable equivalents of the hills. However, the name Valmiki appeared in the Administrative Reports of 1915 onwards. In 1935, the Valmiki, Domb, Paidi, Ghasi are recorded as synonyms. But all these groups maintain that they are different from them. The Domb, or Konda Mala, is officially replaced by the term 'Valmiki'.

4. The acquisition of land by the Valmiki was brought to the notice of the Aiyappan commi-ttee (1948) and Elwin committee (1960) who recommended that the 'alienation' of tribal land to Valmiki should be stopped.

5. The hereditary traditional Peddala Panchayat of every village consists of a Valmiki member (Pedda) besides the Barika (Village servant who is invariably a Valmiki). When this traditional system was replaced by the elected Panchayat, the members were elected as ward members.
So, the presence of Valmiki as an influencial member got many of them co-opted as Vice-Presidents in many villages. During 1980s and early 1990s both the state Legislative assembly seats of Visakhapatnam Agency, viz., Paderu and S. Kota, were represented by Valmiki M.L.As, P. Bala Raju and L.B. Dukku, respectively. Another Valmiki, M.L.A. Mr. Setti Lakshmanudu, became the chairman of State Girijan cooperative corporation. Many Valmikis are now elected to several district bodies and play crucial roles in many political parties in the Agency.

6. The Bagatha claim themselves to be the loyal soldiers of the Raja of Jeypore and Zamindars. They say that the name Bagatha was derived from the word 'Bhakta' meaning the 'loyal one' (Thurston 1909; Vol. 1 : 128).

\section{REFERENCES}

Fuchs, Stephen: The Gond and Bhumia of Eastern Mandla.New Literature Publishing Company, Bombay (1960).

Furer-Haimendorf,Christoph Von: The Reddis of Bison Hills: A Study of Acculturation. Macmillan, London (1945).

Furer-Haimendorf,Christoph Von: Raj Gonds of Adilabad: A peasant culture of Deccan. Macmillan, London (1948).

Hivale, Shyamrao: The Pradhans of Upper Narbada Valley. Oxford University Press, Bombay (1943).

Mandelbaum, David: The Kotas in their social setting. In: Milton Singer (Ed.): Introduction to the Civilization of India. University of Chicago Press, Chicago (1956).

Murty, A.S.: Caste Stratification in Tribal Koya Society. $J$. Ind. Anthrop. Soc.,7(2): 172-177 (1972).

Pareek, R.N.: Tribal Culture in Flux. B.R. Publishing Corporation, Bombay (1977).

Reddy, Muniratnam: The Bhagatha and Related Tribes. unpublished thesis, Andhra University, Waltair (1971).

Reddy, N.S.: Caste in tribal society: The formulative process. Contributions to Indian Sociology, NS, 17: 159-167 (1973).

Reports ofGovernment of Madras, Judicial Department: State Archives, Government of Tamil Nadu, Chennai (18801916).

Shah, Ghanshyam: Ethnic Differentiation and Tribal Identity. Ajanta Publications, New Delhi (1984).

Revenue Department State Archives, Government of Tamil Nadu, Chennai.(1988)

Thasu, K.N.: Inter-ethnic Relationship and Social Mobility among the Dhaswa of Marange. Bull. Dept. Anth., 18(4):17-21 (1959).

Thurston, E.: Castes and Tribes of South India. Cosmos Publications, Delhi, Vol.1: 128 (1975). 